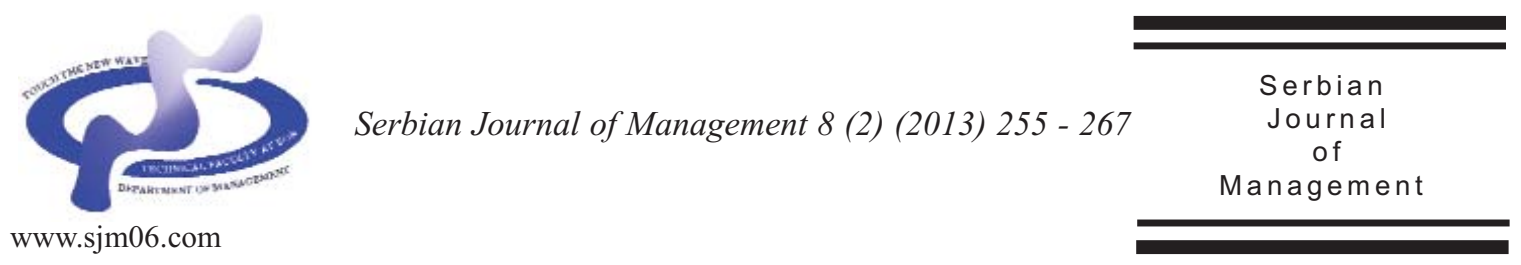

\title{
HOW CAN THE STATE SUPPORT THE INNOVATIONS TO BUILD SUSTAINABLE COMPETITIVE ADVANTAGE OF THE COUNTRY
}

\author{
Anna Zauškováa , Artur Bobovnickýa, ${ }^{*}$ and Adam Madleňák

 \\ University of Sts. Cyril and Methodius, J. Herdu 2, 91701 Trnava, Slovakia

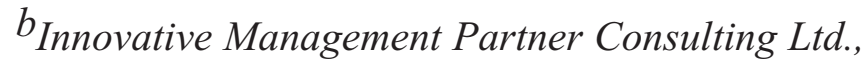 \\ Gunduličova 4, 81105 Bratislava, , Slovakia
}

(Received 8 September 2013; accepted 5 October 2013)

\begin{abstract}
As the crisis gets longer and deeper, growth disparities between some European regions are increasing, there is an even stronger need to accelerate innovation support and deepen it in the areas crucial to innovation, such as higher education, innovation-based entrepreneurship and demand-side measures. Europe needs fresh dynamism in its economy. Existing industries and the countries, too, need to develop new applications and new business models in order to grow and maintain their competitive advantage. This calls for an innovation-driven structural change, attracting top talent and reward innovative entrepreneurs, offering them much better opportunities to start and grow new businesses. Several studies were done exploring the innovations and their importance for the companies to achieve a sustainable competitive advantage. The article describes basic approaches and the model of relationship between key factors and their influence on the construct success of the company. As an outcome from this model it is clear that innovation orientation of the management and ability to launch innovations onto the market are central aspects of the success. The article deals with current status of innovations in Slovakia, identifying what are the preconditions for future development of the environment that is supporting innovations and how are they fulfilled in Slovakia.
\end{abstract}

Keywords: Globalization, innovation, competitiveness, national policies

\section{INTRODUCTION}

After decades of various transformations the companies have become smaller, simpler and much faster in reaction to market demands that ever before. They became more competitive. The same applies for nations. In the fierce competition for foreign

\footnotetext{
* Corresponding author: a.bobovnicky@gmail.com
}

DOI:10.5937/sjm8-4430 
direct investments, innovative scientists etc, nations became more competitive. There is no single recipe for nation competitiveness. One needs to take into account the specific environment, value system and cultural heritage of a country in order to define what is acceptable or not and to draw the consequences and policy implications which are advisable for particular national economy. In our approach we evaluate innovations and effectiveness of innovation process, which is becoming the key factor (and key challenge) for many political and research initiatives focused on nation competitiveness growth. Other expected results of the innovations and effectiveness of innovation process are sustainable development and steady increase of the quality of life of the society. In a quest for nation competitiveness analysis we use certain simplification - comparing nations with the firms in many places of this article, as far as 1) a competitive firm is a key factor of a competitive nation; 2) the competitiveness of firm is well studied and described.

The principal role of the corporate management is effective management of technology operations and processes, that must be adjustable to provide flexible response on customers needs within the limits of production lines. „But it is not enough for a company to streamline and downsize, company must be capable to innovate - fundamentally reconceiving itself, of regenerating its core strategies, and of reinventing its industry" (Tushman et al., 1997). From the nations point of view emphasis is laid on possible modification of socio-economic processes and social models intended for preparation of sufficiently skilled manpower to implement the innovation trends searched for. The importance and the need for innovations aimed at further development of the European Union can be derived from the currently most significant political document formulating the objectives and tasks of the European Community in the future - Europe 2020 Strategy for Growth and Employment.

\section{THE ROLE OF INNOVATIONS IN THE PROCESS OF COMPETITIVENESS GROWTH OF THE FIRMS AND NATIONS}

Last fifty - sixty years in mankind development is marked with several revolutionary changes - many technological, mainly communication and information systems have brought disruptive energy and led to the overall improvement of the lives of human beings; making it easier, but at the same time more interconnected and removing previously known barriers borders and political systems. But the speed of new innovations seems to be slowing down. While markets are constantly overflowed with new products, the really NEW products (disruptive innovations) are rare. Companies everywhere are engaged in a product innovation war with ultimate goal to differentiate. The weapons of this war are the thousands of new products invading chosen marketplaces in order to secure a sustainable competitive advantage. „Unlike a military war, the product innovation war is beneficial one - no deaths, no violence, and no burned buildings. The victors gain riches and fame; the losers are vanquished, merged, or disappear; and society and humankind benefit from the new products and services that previous generation did not have" (Cooper, 2005). But many companies find themselves in unusually precarious 
positions. The market requires continuous quality improvements, companies are not in a position to successfully raise their prices. In many cases, companies are being forced to drop heavily their prices in order to compete. Looking more closely at the situation we see that many of these companies have not systematically adjusted their revenue models to reflect the changes of recent years. This situation is described in Figure 1.



Perceived value by customer

Figure 1. Phenomena of hyper competition. The battlefield is moving towards higher quality and lower price. (D'Aveni, 2007)

Innovations can be considered to be an inseparable part of the country's economic growth in the global economic market conditions. Their primary essence consists of new information resulting from application of natural persons' theoretical knowledge of scientific, research and development activity to the entrepreneurial activity. They can be defined as a "renovation and extension of the product and service range, as well as relating markets, formation of new methods, technologies and production ways, delivery and distribution, implementation of changes in labor management and organization, improvement of work conditions and growth of workers' qualification." The purpose of implementation of innovation activities is a constant increase of business entity performance, which in this way strives to commercialize the original invention. On the other hand, business entity performance is often resulting in wrong (slow, late, or inadequate) reaction on the market feedbacks. We have to bear in mind, that only business entity innovation activities, isolated in the goals and financing could be weakening the final ability of the companies developing and launching new products.

From this perspective, reinforced by the turbulent economic situation worldwide in last five years we can see emergence of the new approach towards investments into innovations. Companies are more open to the flows of new ideas, technologies and solutions from external environment. More stakeholders are incorporated into a new product development. It is called an open innovation and becomes a standard approach for innovations in 21 st century.

The open innovation that Chesbrough describes (Figure 2.) shows the necessity of letting ideas both flow out of the corporation in order to find better sites for their monetization, and flow into the corporation as new offerings and new business models. (Chesbrough et al., 2006).

Achieving the competitive advantage of the country is possible only if all firms will learn, utilize, and develop the external knowledge and will leave the paradigm of necessity being at the initial moment of the new ideal or concept. It is sufficient that firm focuses on profound development of the information available (Sloane, 2011). Antedescant for success of open innovation approach is willingness providing public 
access to the own ideas and innovations, commonly accepted vision. For him, which are not fully utilized by the firm, under the condition that rules of the utilization are clearly defined and agreed. This is to avoid commercial losses and gain reasonable return coming out of the own R\&D activities. countries unlike corporations don't have a bottom line in the sense that they don't try to maximize their citizen's wealth in order not to cease existing because there is nothing the least resembling to bankruptcy as an option for countries. He also denies that trade is a



Figure 2. Open innovations (according Chesbrough, 2013)

\section{COMPETITIVENESS}

Over the years, the debate has been ongoing about the meaning of this word and most citizens lacking important notions in global trade have stuck with the meaning that was most accessible and comprehensible to them, the same meaning President Clinton gave to it during his time in office: "nations are like corporations competing in the global marketplace". This definition implies many things such as the existence of a bottom line for countries and the impossibility of there being two winners in the equation.

Paul Krugman (1994) started the debate by presenting his disapproval of this zero-sum argument. All countries have the possibility of being winners in the world market place through the dynamics of comparative advantage. In Krugman's views, nations are not in economic competition with each other and their problems can't be attributed to their lack of success in competing on the global platform. Indeed, since exports are only $10 \%$ of GNP, countries are not really dependent on their neighbors for success. Success, in the sense of sustainability and high standards of living, is entirely dependent on a country's domestic productivity growth. One key point Krugman wants to get through is that because trade balance is so innocuous, there 
is no need to build domestic polices around it. Doing so would only result in a misallocation of resources and a lack of funding for the service sector, protectionism and bad public policies.

Regardless the fact that countries do not have so called bottom line in classical view, we think that there is close relationship and similarities between successful (competitively looking) companies and countries, and therefore both managers and politicians should learn from Hamel and Prahalad breakthrough thoughts expressed in their article: "Given that change is inevitable, the real issue for managers is whether that change will happen belatedly, in a crisis atmosphere, or with foresight, in a calm and considered manner; whether the transformation agenda will be set by a company's more prescient competitors or by its own point of view; whether transformation will be spasmodic and brutal or continuous and peaceful. Place coups make great press copy, but real objective is a transformation that is revolutionary in result, and evolutionary in execution" (Hamel \& Prahalad, 1994).

Open innovation platform could become nowadays an unique tool not only for reducing uncertainty which is permanently present in own R\&D but simultaneously for increasing the competitiveness of the national economies.

\section{THE NATURE OF COMPETITIVE ADVANTAGE}

IMP has carried out analysis of more than 700 companies from 10 nations which makes it clear that only very few organizations manage to achieve sustainable success (Bailom et al., 2007). Despite their differences, these companies all have one thing in common: they are able to continually create unique benefits in their markets.

This unique quality is in turn the result of a specific ability to reinvent themselves from their core outwards and anticipate future trends in the market.

Peter Brabeck-Letmathe, Chairman of Nestlé, speaking for all of the top performers who were analyzed in this project, sums up this central principle of sustainable success as follows: "It is not a matter of thinking about what made us successful up to now, but more importantly what we can do to be successful in the future" (Bailom et al., 2007).

IMP has managed to clearly show the depth and interconnection of the central principles and elements of entrepreneurial success. As one can see, the set is describing the corporate success on $52 \%$. Is it sufficient or not? $48 \%$, which are not described, are factors like chance, intuition and last, but not least luck. So far, it is the most precise description with mathematical and statistical justification.

The innovation orientation of the management is a key factor, closely followed by culture intensity and its type, core competence management and ability to bring the innovation to the market. The study of IMP is clear confirmations how important are innovations for firms, but could be similarly conceived by the regions and nations. Only continuous quality improvements can ensure competitiveness. As a consequence, only countries that are really successful in supporting and implementing innovations are reaching the top positions in the world rank lists of various competitive indexes. 


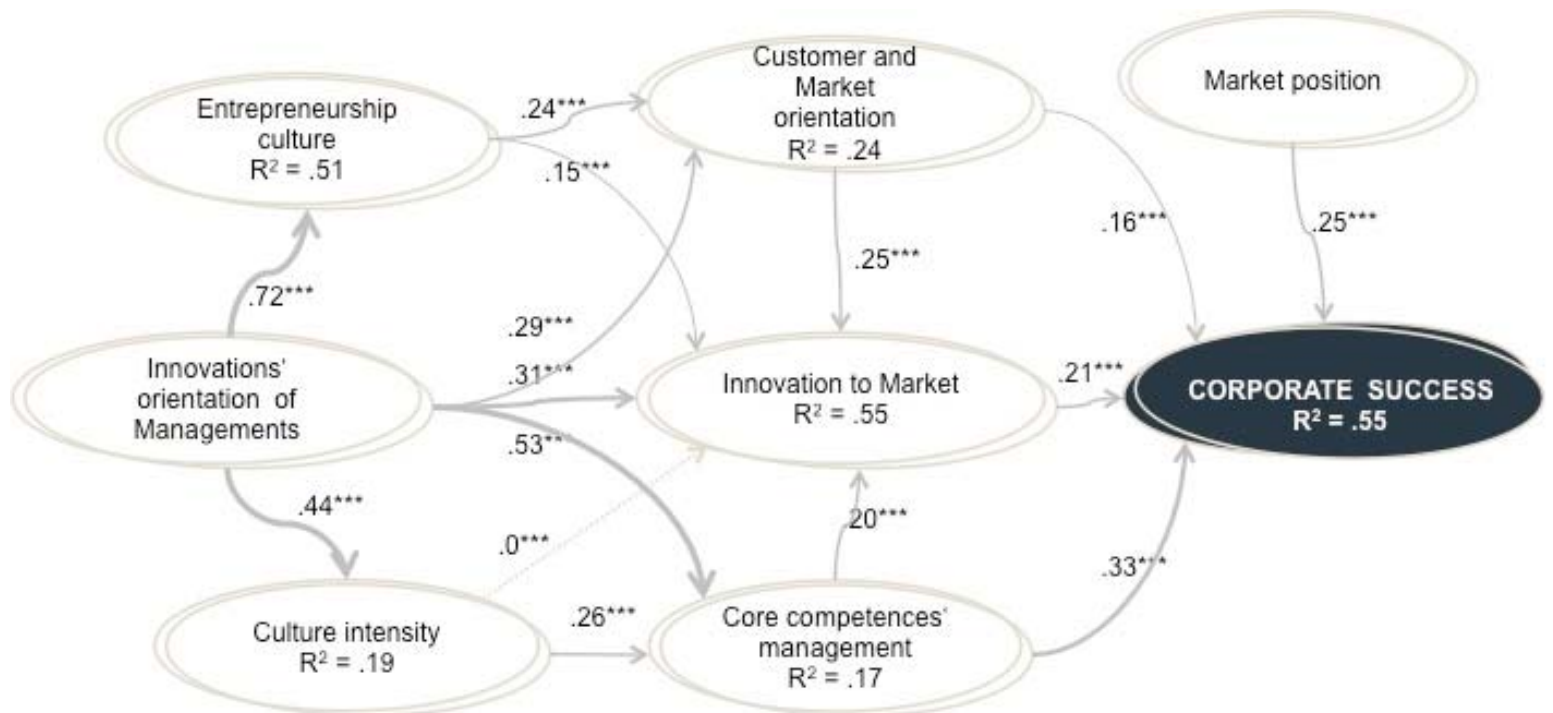

Figure 3. IMP model of the nature of competitive advantage (Bailom et al., 2007)

5. INNOVATION ACTIVITIES IN EU AND IN SLOVAKIA - LEGAL FRAMEWORK

Irrespective of other circumstances influencing the innovation process, its correct legal anchoring at the national and European level can be marked as a significant determinant of successful implementation of specific measures in practice. The suitable legal environment does not participate only in easier transfer of innovative products from the research phase to the retail sale, but also in insurance of sufficient funding, public procurement adjustment for purposes of research and development or, last but not least, in provision of legal protection to innovative products in the area of intellectual property. As a consequence of absence of adequate legal framework the request of mutual cooperation of companies during innovation activities would remain just a formal theoretical starting point, making the real implementation impossible. Elaboration of national legal regulations focusing on science and research support is a relatively complex process, not easy for coordination, professional knowledge and proper consideration of the wide range of mutual ties. It is in particular a connection to the strategic and program documents of the Slovak Republic and the European Union, implementation of relevant industry policies or acquired experience from so far implemented development programs in the respective country. Here, it is important to take into consideration mainly many European framework programs for research and development of technologies, which represent the basic tool of the European Commission for financial support of research activities in the territory of the Community. At the same time they represent the primary legislative tools for the possibility of successful implementation of the unified European research area ${ }^{1}$. It is also inevitable to preserve harmonization with so-called

${ }^{1}$ Establishment of the European Research Area (ERA) results from the political and legislative obligations stated in the Amsterdam Treaty, at the same time, however, it should facilitate the increase of investments in the European research. The concept of the European Research Area is a combination of following elements: European "single market" for research, where free movement of research workers, technology and knowledge takes place; efficient coordination of intra-state and regional research activities, programs and policies at the European level; initiatives implemented and funded at the European level. 
Innovation Union, which represents one of seven main programs ${ }^{2}$ within the Europe 2020 Strategy. The aim of the Innovation Union is to harmonize the rules for provision of tax reliefs and improve the conditions for access to the financial incentives for support of development of science and research in the EU member states. In the context of proposed measures within the Innovation Union the attempt to create a unified European patent mechanism can be deemed to be significant. Inappropriate and often different regulations or procedures of states in management of rights to intellectual property usually build a severe obstacle in enforcing their research activity results abroad.

The European legislative starting points, as well as enduring, not pleasing standing of the Slovak Republic in innovation performance and innovation potential evaluation of member states of the European Union $^{3}$, open for the national legislator a number of challenges and requests for reform of the existing science and technology system with the prerequisite of bigger openness and adaptability to new trends in the field of innovation process. Legal framework of science, technological development and innovations in the Slovak Republic can be at the same time marked at least as insufficient, and moreover, inappropriately complicated. Despite multiple repeated attempts and amendments of the legal framework, which should have implemented a conceptual management of scientific-research activities, the situation regarding support of research is split among several central state administration bodies and allowance organizations funded by them. At present there is no efficiently applied, unified, long-term innovation strategy with clearly defined parameters of its practical implementation in Slovakia. Likewise, no unified functional innovation system, which would consist of scientific institutions, policies, programs and instruments creating favorable conditions for support of innovations and increasing competitiveness of the country economy is in place.

The fundamental basis of the weak development of science and research, in particular the innovation process, originates mainly from different model of economy management before 1989, which was focused predominantly on central planning and showed a low rate of adaptability to changed market conditions. Positive moment of socialist science and research management was, however, the obligation of business entities to invest considerable funds in the support of research activities. On the other hand, science and research concentrated predominantly on heavy engineering industry, which was given also by a number of armament factories in the territory of former Czechoslovakia (Zajac, 2002). Later, however, it was mainly due to the economy transformation from central to market economy, which significantly weakened the implementation of research activity in small and medium enterprises.

\footnotetext{
${ }^{2}$ The initiative of the Innovation Union develops along with the industrial policy for the period of globalisation, the aim of which is an ensurance of strong, competitive and diversified production value chain with a specific emphasis on small and medium enterprises. Similarly, it complements further significant initiatives, such as the Digital program, Youth in motion or Program for new skills and new jobs.

${ }^{3}$ Based on the last evaluation Innovation Union Scoreboard 2013, the Slovak Republic is ranked among the evaluated countries with the least innovation efficiency. Out of 27 countries of the European Union it took only 20th place. The European Union marked extremely low expenditure on the public and private sector for science and research to be the most likely reason for Slovakia's failure. Compared to other member states of the European Union the expenditure on research and development in the Slovak Republic are among the lowest ones, moreover, with decreasing tendency. While average of expenditures of the European Union countries on research and development represents $1.82 \%$ of gross domestic product (GDP), in Slovakia it is only $0.48 \%$ of GDP, whereas public funds amount to as much as 55 $\%$ of total cost of science and research. Due to delayed availability of data, the evaluation outlined reflects the situation in the society in $2010-2011$.
} 
More significant attempts to start innovation processes according to the WestEuropean model can be identified only after 2000, when measures to improve framework conditions of research activity management were repeatedly taken. Respective interventions, unfortunately, were in most cases limited only to enterprises with private foreign capital, bringing established customs from parent companies. At that time, the fundamental document in science and research development was the Concept of State Scientific and Technical Policy until 2005, adopted by the government of the Slovak Republic by means of decree No. 724 of 13 September 2000. The aim of the program was creation of an adequate economic, legal and institutional setting, allowing the Slovak Republic to enter the structures of the European Union with reference to facilitation of the entire integration attempt while constituting the common European research area.

Consequently, in 2005 the government of the SR adopted the Competitiveness Strategy of Slovakia until 2010. In connection to the strategy the Action plan for science, research and innovations was passed. One of the crucial tasks of the action program was a program preparation to popularize science in society intended for public awareness increase regarding the researcher's work, clarification of the meaning and importance of development of new products and encouragement to participation in many interesting projects (Švec, 2012). Based on the action plan described, so-called Central information portal for science, research and innovations was established. The information portal represents a national information system for science and innovations to monitor the data on development and solutions of research- development projects, funded from public resources, as well as on the possibilities of mobility of research workers within Slovakia and whole Europe.

In connection to the funding of research projects, it is also necessary to point out the existence of the Innovation fund, established by the Ministry of Economy in accordance with the provisions of Act No. 147/1997 Coll. on Non-investment Funds. Provision of financial support from the fund reserves is performed by means of recoverable financial contribution for organisations intending to execute research activities that are highly likely to achieve the required market result. Substance of loans from the innovation fund lies predominantly in awarding highly favourable conditions compared to commercial banks (Štofkova, 2012).

The opportunity to support extraordinarily progressive and economically advantageous solutions of existing problems is offered by the Slovak Research and Development Agency (APVV) founded based on Act No. 172/2005 Coll. on Organization of State Support for Research and Development and on amendment to Act No. 575/2001 Coll. on Organization of Activities of the Government and Central State Administration as amended, as well as by the Scientific Grant Agency (VEGA) of the Ministry of Education, Science, Research and Sport of the Slovak Republic and of the Slovak Academy of Science. It is their task to facilitate research project implementation using the funds allocated from the state budget of the Slovak Republic.

Situation in national support of science and research came noticeably forth also in 2007, when the National Strategic Reference Framework for Planned Economic and Social Development of the Slovak Republic in 2007 - 2013 was adopted. The National 
Investments from public sources have been tripled

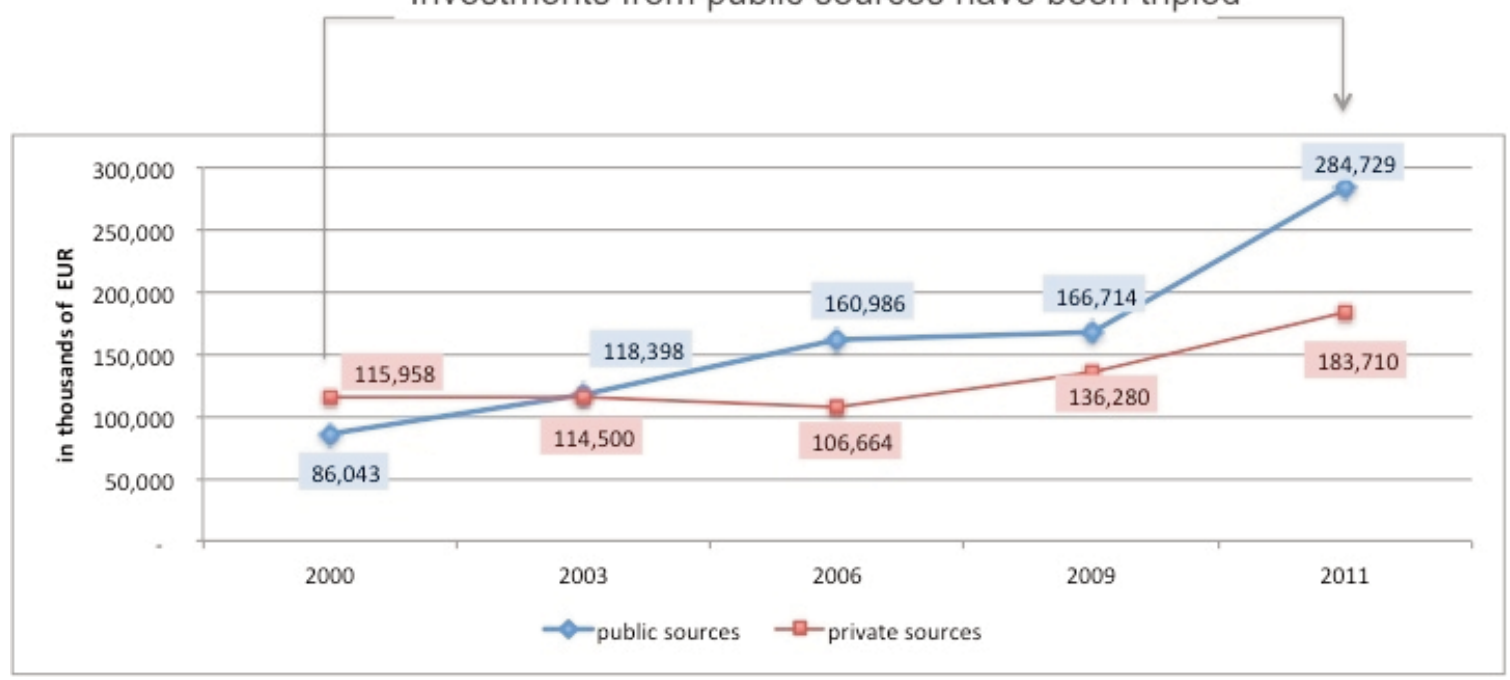

Figure 4. Public and private investments into innovations in Slovakia 2000-2011 (Statistical office of the Slovak Republic, 2013)

Strategic Reference Framework was prepared under the supervision of the European Commission and was several times re-worked in line with its conditions. At present it represents the basic strategic document for use of funds from the Structural Funds of the European Union and the Cohesion Fund. In the mentioned period the government of the Slovak Republic adopted also the proposal of the Innovation Strategy of the Slovak Republic for 2007 2013. The innovation policy of the SR 2008 - 2010 and later $2011-2013$ in jurisdiction of the Ministry of Economy of the Slovak Republic focused on closer elaboration of specific measure presented in the innovation strategy. The task of the innovation policy of the SR was not only a continual insurance of volume of funds spent on science and research, but also support of society development towards innovation and creativity. Measures selected focus on removal of obstacles of cross-border cooperation and mobility of research workers, establishment of partnerships between business entities and universities; they concentrate on quality increase of master's education or promotion of scientific knowledge using the open access to publications and data from the publicly funded research (Ministry of Economy, 2010).

Similarly, the innovation strategy of the Slovak Republic for 2007 - 2013 was supplemented by so-called Long-term Intent of the State Scientific and Technological Policy till 2015, adopted by the resolution of the SR No. 766/2007, which has been recently amended by so-called Fenix Strategy (2011). Fenix brought again several system changes in science and research funding in Slovakia, and at the same unambiguously identified the tasks of the state machinery in this area.

Besides the documents mentioned, also Minerva project 2.0 should help improve competitiveness of the Slovak Republic and support development of knowledge-based economy. The action plans of Minerva 2.0 bring after all principal reforms of methods of professional education, formation of information-based society and development 
of entrepreneurial environment. Examples of such reform measures are for example establishment of a new grant system for applied and academic research, foundation of grant program of M. R. Štefánik or migration policy update with regard to inflow of highly qualified scientists from abroad.

Fragmentation of competencies in science and research in the Slovak Republic between the central state administration bodies outlined above clearly induces a relatively low efficiency of innovation system, the feature of which are in particular insufficiently developed coordination and consultancy mechanisms of responsible institutions. And although the state investment into innovations were increased it is still far behind the OECD countries.

Although the Government Council of the SR for Science and Technology, where all stakeholders were involved, should have originally helped solve this problem in the long run, the research community and industrial associations preferred a formulation of theoretical starting points of the state scientific and technological policy to preparation and implementation of concrete innovation policy measures. Consequently, the result was a weak interconnection of the basic and applied research and relatively complex segmentation of competencies in connection to the innovation activity management, which is currently supervised by the Ministry of Economy of the Slovak Republic, disposing of managing competencies and in the area of development of scientificresearch activities it is the Ministry of Education, Science, Research and Sport of the Slovak Republic. Both are at the same time authorized and obliged to fulfill their obligations arising out of the membership of the SR in the European Union in accordance

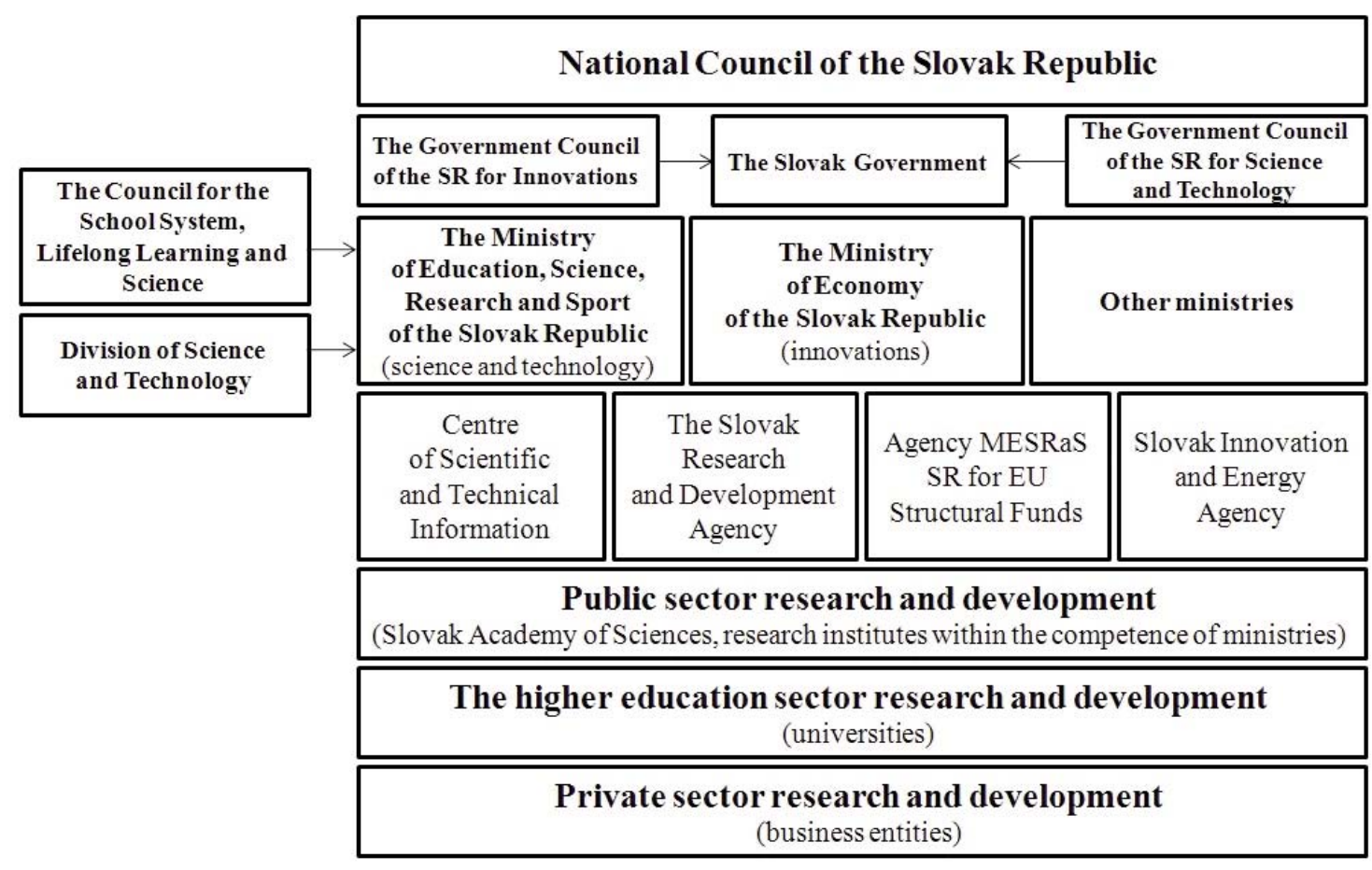

Figure 5. The framework of the $R \& D$ policy in Slovak Republic 
with the Europe 2020 Strategy and Innovation Union.

As the problem of innovations obviously surpasses the borders of one department and the situation described was, from the longterm point of view, unsustainable for the Slovak Republic, the Slovak government established based on Resolution of 28 September 2011 the Government Council of the SR for Innovations with the primary aim to strengthen the coordination of implemented innovation measures for the upcoming period. However, at present we are not able to state with certainty that the new body will be able to fulfill the objectives set in support of the national innovation process, mainly based on the existing experience from previous similar institutions. Thus, expected changes would repeatedly become only formal concepts without adequate application results.

\section{CONCLUSION}

It is getting harder and harder to differentiate oneself from the competitors, their products and services, resulting in fierce competition in terms of product quality and price. In the long run, survival in this competitive environment, and defense of one's position, depends crucially on continuous innovation and improved offers or apparent price advantage.

The results of several analyses confirm, that many companies in Central Europe (but the statement is not limited to this region only) are caught in a downward spiral, a situation in which they are subject to enormous pressure to constantly improve the quality of their products and services while there is little room to increase prices.
The European Union and its member states do not have a large choice while ensuring future sustainability of own economic area, just to adapt to the current global innovation trends. At the same time, the ability to innovate quickly and cheaply in the interest of market share preservation in the strongly competitive market becomes inevitable. One of possibilities how to meet the expectations is the effort of the states to support mutual cooperation of business entities using the respective legal regulations. „Government's proper role is as a catalyst and challenger. It is to encourage, or even push, companies to raise their aspirations and move to higher levels of competitive performance, even though this process may be unpleasant and difficult. Government plays a role that is inherently partial, and that succeeds only when working in tandem with favorable underlying conditions in the diamond. Government policies that succeed are those that create an environment in which companies can gain competitive advantage rather than those that involve government directly in the process ${ }^{\text {“6 }}$ (Porter, 1991).

Though the Slovak concepts of science and research development at first sight faithfully copy the requests set in different European legislations, their fulfillment, with regard to specific conditions of the SR, will represent a demanding task in the future. We assume that the basic insufficiency will still result from not existing complex access to formation and support of research activities. Establishment of various coordination authorities cannot namely remove their continuing differentiation between different central state administration bodies either. Although they can contribute to better information of the stakeholders, they, however, cannot have a direct impact on 
their decision-making process, as e.g. the current legal state, the issue of ministries will constantly act as independent innovations could be shifted to the Ministry administration bodies in the process of of Education, Science, Research and Sport of allocation of funds to concrete projects. the Slovak Republic) and at the same time it Analogically, problem may arise while would dispose of the competencies regarding considering just the general character of all documents described, individual state official can interpret formulations differently. Thus, the solution could be the establishment of a certain "super-ministry" or another central state administration body, which would cover the entire science and research or innovation area (with regard to observance of the national innovation strategy set. Developing shared expectations among all stakeholders to promote innovation takes time and requires absolute consistency by all responsible at all levels and constant repetition of messages.

Announcement: This contribution was elaborated within the research project VEGA 1/0900/12 titled „Increase of innovation efficiency and innovative capability of business entities using the system of open innovations with support of integrated marketing communication.".

\title{
КАКО ДРЖАВА МОЖЕ ПОДРЖАТИ ИНОВАТИВНОСТ ДА БИ ПОСТИГЛА ОДРЖИВУ КОНКУРЕНТСКУ ПРЕДНОСТ
}

\author{
Anna Zaušková, Artur Bobovnický, Adam Madleňák
}

Извод

Како се криза продубљује и продужава, разлике у интензитету раста између појединих региона Европе, такође расту. Самим тиме, јавља се још јача потреба за убрзањем подршке иновацијама, посебно у областима које су кључне за иновативност, као што су високо образовање, предузетништво засновано на иновацијама као и мере из угла пвовећања тражње. Европа захтева свежу динамичност своје економије. Развијене индустрије у земљама ЕУ, такође требају да развију нову примену постојећих, као и нове пословне моделе, како би расле и одржале своју конкурентску позицију. Ово захтева структурну промену засновану на иновацијама, уз привлачење најталентованијих и стручних иновативних предузетника, уз пружање много бољих услова за започињање и раст њиховог бизниса. Већ су урађене бројне студије које су истраживале иновације и њихову важност за компаније да би постигле одрживу конкурентску предност. Овај рад описује основни приступ и модел односа између кључних фактора и њихов утицај на конструктивни успех компаније.Као исход овог модела, јасно је да су оријентација ка иновацији менаџмента, као и могућност апликације иновација на тржишту, централни аспекти успеха. Овај чланак се бави и тренутним статусом иновација у Словачкој, идентификујући предуслове за даљи развој окружења које подржава иновације и како су оне прихваћене у Словачкој.

Кључне речи: глобализација, иновација, конкуренција, национална политика 


\section{References}

Bailom, F., Matzler, K., \& Tschemernjak, D. (2007). Enduring Success. New York, USA: Palgrave McMillan.

Chesbrough, H., Vanhaverbeke, W., \& West, J. (2006). Open Innovation: Researching a new Paradigm. Oxford, UK : Oxford University Press.

Cooper, R.G. (2005). Product Leadership. New York, USA: Basis Books.

D’Aveni, R.A. (2007). Mapping Your Competitive Position. Harvard Business Review, 85(11): 110-120.

Hamel,G., \& Prahalad, C.K. (1994). Competing for the Future. Boston, USA: Harvard Business Review.

Krugman, P. (1994). Competitivness: A Dangerous Obsession. Foreign Affairs, 72(2): 28-44.

Ministry of Economy of the Slovak Republic (2010). Innovation policy for years 2011 - 2013 in the department of the Ministry of Economy of the SR. (In Slovak).

Porter, M.E. (1991). Towards a Dynamic Theory of Strategy. Strategic Management Journal, 12: 95-117.

Sloane, P. (2011). A Guide to Open Innovation and Crowdsourcing: Advice From Leading Experts. London, UK: Kogan Page.

Slovak Statistical Office: http://portal.statistics.sk/showdoc.do?docid= 7196

Štofková, K. (2012). Public expenditures. In Štofková, J. et al., Funds and financial management. University textbook. Žilina : EDIS Publisher. (in Slovak)

Švec, M. (2012). Culture of labor world: Dependent work and agreements on work performed outside employment. Bratislava, Slovakia: Friedrich Ebert Stiftung. (In Slovak).
Tushman, M.L., \& O'Reilly III, Ch.A. (1997). Winning through Innovations. Boston, USA: Harvard Business School Press.

Zajac, Š. (2002). Innovation and Slovakia. Pp 45-54 In: Second Multinational Panel Meeting - Innovation Policy Issues in Seven Candidate Countries: The Challenges. Luxembourg, European Commission DG. 